\title{
Dynamic Game and Simulation Analysis in Railway Technical Regulation Supervision
}

\author{
Fuqiang HAN ${ }^{1}$, Chengcheng $\mathrm{LI}^{1}$, Xiang XIE ${ }^{1}$ \\ ${ }^{1}$ School of Economics and Management, Beijing Jiaotong University, Beijing, 100044, China
}

\begin{abstract}
In order to discuss the factors that affect the regulation behavior of railway technical regulations and perfect the regulation mode, a game model with $\mathrm{CRG}$, railway bureau and railway station as the main body of regulation is constructed. The results show that the intensity and cost of rewards and punishments have an impact on the railway technical regulations and supervision system.
\end{abstract}

\section{Introduction}

The supervision system of railway technical rules is an important part of the basic railway management. A scientific and reasonable supervision system is conducive to realizing the standardized management of railway technical rules, promoting a stable order of railway transport safety in production and effectively improving the efficiency of railway transport management and traffic organization. At present, China has basically formed a system with the technical regulations of the China Railway Group as the core, and classified management according to the basic technical rules and professional technical rules. Although the supervision system of railway technical regulations has been preliminarily formed, there are still some problems such as unreasonable structure and non-standard supervision. Therefore, the study on the interest game of CRG, railway bureau and railway station in the supervision of railway technical regulations is beneficial to $\mathrm{CRG}$ to promote the upgrading of railway supervision system.

At present, the research on technical regulations mostly focuses on qualitative analysis, architecture and optimization strategy. Jin Guo analyzed the current situation of the system of railway technical regulations, and clearly divided the authority and scope of different levels ${ }^{[1]}$. Xin Liu combed the development context and constructed the framework of railway technical regulations ${ }^{[2]}$.Yonggang Jia studied the changing mechanism of railway technical regulations from three aspects of demand, supply and utility, and analyzed the changing trend and emphasis ${ }^{[3]}$. Min Kuang proposed that the system of technical regulations consists of technical regulation framework, management mechanism and information system, and the optimized scheme is obtained by horizontal comparison ${ }^{[4]}$. Yujia Wang et al. evaluated the quality of technical regulations by constructing fuzzy comprehensive evaluation model, and put forward the index system of standardized technical regulations [5]. Fuqiang Han, et al., analyzed the equilibrium solution of the expected return of the China Railway Group, the Railway Administration and the railway stations by using dynamic game theory, and considered that the management cost of technical regulations and the strength of superior management are the important factors affecting the implementation of technical regulations ${ }^{[6]}$. Xiaotao Zhao has established a railway technical regulation management system based on the SSM framework to enhance standardized management and collaboration among various units ${ }^{[7]}$. Xiaojie Wang analyzed the factors that affect the diffusion of technical regulations, and explained the strategic choice of stakeholders in the diffusion of technical regulations by establishing a game model ${ }^{[8]}$.

With the application of game theory and system dynamics in many fields, this research method has been gradually applied to -supervision. Kehong $\mathrm{Li}$ and his colleagues set up an evolutionary game model of HSR regulation system, and revealed the stability and behavior characteristics through system dynamics simulation ${ }^{[9]}$. Lu Jia used system dynamics to establish a multi-party dynamic evolution game model in safety supervision of engineering construction, and put forward the improvement strategy of dynamic supervision ${ }^{[10]}$. Shixin $\mathrm{Li}$ simulated and analyzed the online car-hailing supervision system through evolutionary game and system dynamics methods, and explored the impact of different supervision methods on the supervision effect [11]. Min Cheng set up a game model of building safety supervision, and analyzed the dynamic influence of different variables on building safety through system dynamics ${ }^{[12]}$. Ya Gao set up a game model between supervision unit and construction contractor, and simulated the dynamic evolution process of safety supervision in construction engineering ${ }^{[13]}$. Quanlong Liu constructed a game model of coal mine safety supervision system, and combined with system dynamics to analyze the equilibrium point stability of the game

xxie@bjtu.edu.cn 
model ${ }^{[14]}$. In view of this, this paper sets up a game model based on CRG, railway bureau and railway station, and studies the problem of railway technical regulation with system dynamics method.

\section{Development on Game Model of Railway Technical Regulations Supervision}

\subsection{Model Hypothesis}

(1) Assume game participants--China Railway Group, railway bureau and railway stations are all rational economic people. Follow the principle of maximization of rationality, and use policy utility as the basis for actions. Different combinations of actions selected will lead to different costs and benefits, which in turn determines the equilibrium result of the game.

(2) Assume that the market information is complete, that is, China Railway Group, railway bureau and railway stations have a clear understanding of each other's characteristics, strategic space, and payoff function.

(3) Assume that the costs of strengthening supervision of China Railway Group is $C_{1}$; the economic and social benefits which is brought by the safe, stable and healthy development of railway transportation is $R_{1}$, at this time, the benefits allocated by China Railway Group to railway bureau is $R_{2}$; the loss of economic and social benefits to China Railway Group when there is a problem with railway transportation safety is $L_{1}$, at this time, railway bureau will be punished $L_{2}\left(L_{1}>R_{1}\right.$, $L_{1}>L_{2}$ ); when China Railway Group supervised railway bureau not carefully refine it, railway bureau will be punished, and the fine income will be $\mathrm{C}_{2}$; as long as railway station implements precisely, the increase in passenger and freight volume caused by the improvement of safety and efficiency will bring benefits to China Railway Group as $Q_{1}$, which will be allocated to railway bureau $Q_{2}\left(Q_{1}>Q_{2}\right)$.

(4) Assume that railway bureau carefully refine the implementation of the railway technical regulations of China Railway Group, increase management costs $C_{2}$; if railway bureau simply implements the railway technical regulations of China Railway Group and does not carefully refine it, it will cause an increase in potential safety hazard, the penalty is $\mathrm{C}_{2}$ (a is the penalty factor, $\mathrm{a}<1$ ); when railway transportation is safe, stable and healthy, the benefits allocated by China Railway Group to railway bureau is $R_{2}$, the benefits allocated by railway bureau to railway stations is $R_{3}$; when there is a problem with railway transportation safety, railway bureau accepts the penalty $L_{2}$ from China Railway Group, and imposes the penalty $L_{3}$ on railway station $\left(L_{2}>R_{2}\right.$, $L_{2}>L_{3}$ ); if railway bureau finds that railway station has not implemented after careful refinement, it will impose the penalty $\mathrm{b} C_{3}$ on railway station; as long as railway station implements precisely and the improvement of safety and efficiency makes passenger and freight volume increase, China Railway Group will allocate benefits $Q_{2}$ to railway bureau, and railway bureau will allocate benefits $Q_{3}$ to railway station $\left(Q_{2}>Q_{3}\right)$.

(5) Assume that railway station implements scientific and effective railway technical regulations, additional expenditure required for detailed regulations, equipment maintenance and maintenance costs is $C_{3}$, which is to standardize management, improve equipment utilization efficiency, and reduce losses; if the strategy of railway station is not implemented after railway bureau's careful refinement, railway transportation will increase safety risks, safety costs, and reduce transportation efficiency. Railway bureau will impose the penalty on railway station as $\mathrm{b} C_{3}$ ( $\mathrm{b}$ is the penalty factor, $\mathrm{b}<1$ ); when railway transportation has safe, stable and healthy development, the benefits allocated by railway bureau to railway station is $R_{3}$; when railway transportation has safety problem, railway station shall be punished by railway bureau $L_{3}\left(L_{3}>R_{3}\right)$; as long as railway station implements precisely, safety and efficiency make passenger and freight volume increase, the benefits will be allocated by railway bureau to railway station is $Q_{3}$.

(6) Assume that there is a downward cost transfer, that is, if China Railway Group has deregulation, railway bureau still wants to carefully refine the railway technical regulations. At this time, the cost of China Railway Group is transferred to railway bureau. Railway bureau's refinement cost is $\left(C_{1}+C_{2}\right)$; if China Railway Group strengthens supervision but railway bureau simplifies the implementation, railway station still wants to implement the railway technical regulations. At this time, the refinement's cost $C_{2}$ of railway bureau is transferred to railway station. The refinement's cost of railway station is $\left(C_{2}+C_{3}\right)$; if China Railway Group has deregulation and railway bureau simplifies the implementation, railway station still wants to implement the railway technical regulations. At this time, the cost of China Railway Group and railway bureau is transferred to railway station. The refinement's cost of railway station is $\left(C_{1}+C_{2}+C_{3}\right)$.

(7) Assume that the probability of safety railway transportation is $P_{4}$. Since judging whether the railway technical regulations really achieve the standard effect is mainly based on whether they are actually implemented at the basic level of railway station, it is assumed that $P_{4}=\mathrm{m}+\frac{P_{1}+2 * P_{2}+3 * P_{3}}{6}(\mathrm{M}-\mathrm{m})$, where $0<\mathrm{m}<\mathrm{M}<1$. When China Railway Group, railway bureau, and railway station are not working properly, the probability of safety railway transportation is the smallest, which is m; when China Railway Group, railway bureau, and railway station are all working diligently, the probability of safety railway transportation is the largest, which is $\mathrm{M}$.

\subsection{Model Building}

According to the above assumptions, the game model has two situations: safety railway transportation and safety problems. Each situation has 8 strategy profiles, which are represented by node 1-node 16, according to (China Railway Group, railway bureau, railway station) the sequence, the strategy represented by each node and its 
payoff vector $\mathrm{Si}$ are shown in Tables 1 and $2, \mathrm{~S}_{\mathrm{i}}=\left(\mathrm{S}_{\mathrm{i} 1}, \quad \mathrm{~S}_{\mathrm{i} 2}, \mathrm{~S}_{\mathrm{i} 3}\right), \mathrm{i}=1, \ldots, 16$.

Table 1 The strategy represented by each node during safety railway transportation and its payoff vector $\mathrm{Si}$

\begin{tabular}{|c|c|c|}
\hline Node & Strategy Profile & Payoff Vector \\
\hline 1 & $\begin{array}{l}\text { (strengthen supervision, carefully refine, } \\
\text { implement) }\end{array}$ & $\begin{array}{l}\mathrm{S}_{1}=\left(-\mathrm{C}_{1}+\mathrm{R}_{1}-\mathrm{R}_{2}+\left(\mathrm{Q}_{1}-\mathrm{Q}_{2}\right), \mathrm{R}_{2}-\mathrm{R}_{3}-\mathrm{C}_{2}\right. \\
\left.+\left(\mathrm{Q}_{2}-\mathrm{Q}_{3}\right), \mathrm{R}_{3}-\mathrm{C}_{3}+\mathrm{Q}_{3}\right)\end{array}$ \\
\hline 2 & $\begin{array}{l}\text { (strengthen supervision, carefully refine, not } \\
\text { implement) }\end{array}$ & $\begin{array}{l}\mathrm{S}_{2}=\left(-\mathrm{C}_{1}+\mathrm{R}_{1}-\mathrm{R}_{2}, \mathrm{R}_{2}-\mathrm{R}_{3}-\mathrm{C}_{2}+\mathrm{bC}_{3}, \mathrm{R}_{3^{-}}\right. \\
\left.\mathrm{bC}_{3}\right)\end{array}$ \\
\hline 3 & $\begin{array}{l}\text { (strengthen supervision, simply refine, } \\
\text { implement) }\end{array}$ & $\begin{array}{l}\mathrm{S}_{3}=\left(-\mathrm{C}_{1}+\mathrm{R}_{1}-\mathrm{R}_{2}+\mathrm{aC}_{2}+\left(\mathrm{Q}_{1}-\mathrm{Q}_{2}\right), \mathrm{R}_{2}-\right. \\
\left.\mathrm{R}_{3}-\mathrm{CC}_{2}+\left(\mathrm{Q}_{2}-\mathrm{Q}_{3}\right), \mathrm{R}_{3}-\left(\mathrm{C}_{2}+\mathrm{C}_{3}\right)+\mathrm{Q}_{3}\right)\end{array}$ \\
\hline 4 & $\begin{array}{l}\text { (strengthen supervision, simply refine, not } \\
\text { implement) }\end{array}$ & $\mathrm{S}_{4}=\left(-\mathrm{C}_{1}+\mathrm{R}_{1}-\mathrm{R}_{2}+\mathrm{aC}_{2}, \mathrm{R}_{2}-\mathrm{R}_{3}-\mathrm{aC}_{2}, \mathrm{R}_{3}\right)$ \\
\hline 5 & (deregulation, carefully refine, implement) & $\begin{array}{c}S_{5}=\left(R_{1}-R_{2}+\left(Q_{1}-Q_{2}\right), R_{2}-R_{3^{-}}\right. \\
\left.\left(C_{1}+C_{2}\right)+\left(Q_{2}-Q_{3}\right), R_{3}-C_{3}+Q_{3}\right)\end{array}$ \\
\hline 6 & $\begin{array}{l}\text { (deregulation, carefully refine, not } \\
\text { implement) }\end{array}$ & $\begin{array}{l}\mathrm{S}_{6}=\left(\mathrm{R}_{1}-\mathrm{R}_{2}, \mathrm{R}_{2}-\mathrm{R}_{3^{-}}\left(\mathrm{C}_{1}+\mathrm{C}_{2}\right)+\mathrm{bC}_{3}, \mathrm{R}_{3^{-}}\right. \\
\left.\mathrm{bC}_{3}\right)\end{array}$ \\
\hline 7 & (deregulation, simply refine, implement) & $\begin{array}{l}S_{7}=\left(R_{1}-R_{2}+\left(Q_{1}-Q_{2}\right), R_{2}-R_{3}+\left(Q_{2}-\right.\right. \\
\left.\left.Q_{3}\right), R_{3}-\left(C_{1}+C_{2}+C_{3}\right)+Q_{3}\right)\end{array}$ \\
\hline 8 & (deregulation, simply refine, not implement) & $S_{8}=\left(R_{1}-R_{2}, R_{2}-R_{3}, R_{3}\right)$ \\
\hline
\end{tabular}

Table 2 When security problem occurs, the strategy represented by each node and its payoff vector $\mathrm{Si}$

\begin{tabular}{|c|c|c|}
\hline Node & Strategy Profile & Payoff Vector \\
\hline 9 & $\begin{array}{l}\text { (strengthen supervision, carefully refine, } \\
\text { implement) }\end{array}$ & $\begin{array}{l}S_{9}=\left(-C_{1}-L_{1}+L_{2}+\left(\mathrm{Q}_{1}-\mathrm{Q}_{2}\right), L_{3}-L_{2}-C_{2}+\right. \\
\left.\quad\left(\mathrm{Q}_{2}-\mathrm{Q}_{3}\right),-L_{3}-C_{3}+\mathrm{Q}_{3}\right)\end{array}$ \\
\hline 10 & $\begin{array}{l}\text { (strengthen supervision, carefully refine, not } \\
\text { implement) }\end{array}$ & $\begin{array}{l}S_{10}=\left(-C_{1}-L_{1}+L_{2}, \quad L_{3}-L_{2}-C_{2}+\mathrm{b} C_{3}, \quad-L_{3}-\right. \\
\left.\mathrm{b} C_{3}\right)\end{array}$ \\
\hline 11 & $\begin{array}{l}\text { (strengthen supervision, simply refine, } \\
\text { implement) }\end{array}$ & $\begin{array}{l}S_{11}=\left(-C_{1}-L_{1}+L_{2}+\mathrm{a} C_{2}+\left(Q_{1}-Q_{2}\right), L_{3}-\right. \\
\left.L_{2}-a C_{2}+\left(Q_{2}-Q_{3}\right),-L_{3}-\left(C_{2}+C_{3}\right)+Q_{3}\right)\end{array}$ \\
\hline 12 & $\begin{array}{l}\text { (strengthen supervision, simply refine, not } \\
\text { implement) }\end{array}$ & $S_{12}=\left(-C_{1}-L_{1}+L_{2}+\mathrm{a} C_{2}, \quad L_{3}-L_{2}-\mathrm{a} C_{2}, \quad-L_{3}\right)$ \\
\hline 13 & (deregulation, carefully refine, implement) & $\mid \begin{array}{c}S_{13}=\left(-L_{1}+L_{2}+\left(Q_{1}-Q_{2}\right), L_{3}-L_{2}-\right. \\
\left.\left(C_{1}+C_{2}\right)+\left(Q_{2}-Q_{3}\right),-L_{3}-C_{3}+Q_{3}\right)\end{array}$ \\
\hline 14 & $\begin{array}{l}\text { (deregulation, carefully refine, not } \\
\text { implement) }\end{array}$ & $\begin{array}{l}S_{14}=\left(-L_{1}+L_{2}, L_{3}-L_{2}-\left(\mathrm{C}_{1}+C_{2}\right)+\mathrm{b} C_{3},-\right. \\
\left.L_{3}-\mathrm{b} C_{3}\right)\end{array}$ \\
\hline 15 & (deregulation, simply refine, implement) & $\begin{array}{c}S_{15}=\left(-L_{1}+L_{2}+\left(Q_{1}-Q_{2}\right), L_{3}-L_{2}+\right. \\
\left.\left(Q_{2}-Q_{3}\right),-L_{3}-\left(C_{1}+C_{2}+C_{3}\right)+Q_{3}\right)\end{array}$ \\
\hline 16 & (deregulation, simply refine, not implement) & $S_{16}=\left(-L_{1}+L_{2}, L_{3}-L_{2},-L_{3}\right)$ \\
\hline
\end{tabular}

After determining the payoff vector of each strategy, the reverse induction method is used to solve the dynamic game equilibrium. So the order of the solution is railway station -railway bureau-China Railway Group. Firstly, we should find the maximum benefit solution of railway station, and then go back to the previous stage of the game to solve the maximum expected benefit solution of railway bureau, and finally determine the optimal solution of China Railway Group. Therefore, the dynamic game equilibrium solution of the three stakeholders can be obtained.

(1) The equilibrium solution of railway station's expected income

The equilibrium solution of railway station's expected income $Y_{3}$ is:

$$
Y_{3}=P_{4} * \sum_{i=1}^{8}\left(q_{i} * S_{i 3}\right)+\left(1-P_{4}\right)^{*} \sum_{i=9}^{16}\left(q_{i} * S_{i 3}\right)
$$

$P_{4}=\mathrm{m}+\frac{P_{1}+2 * P_{2}+3 * P_{3}}{6}(\mathrm{M}-\mathrm{m})$, where $0<\mathrm{m}<\mathrm{M}<1$

In order to find the maximum value of the above function, the first derivative of the probability of railway station's implementation $\mathrm{P}_{3}$ is calculated and made to be equal to zero.

The solution result is: $P_{1}=1-$ $\frac{\frac{\mathrm{M}-\mathrm{m}}{2}\left(\mathrm{R}_{3}+\mathrm{L}_{3}\right)+\mathrm{Q}_{3}-\left(1-\mathrm{b} * \mathrm{P}_{2}\right) * \mathrm{C}_{3}}{\left(1-\mathrm{P}_{2}\right) * \mathrm{C}_{1}}+\frac{\mathrm{C}_{2}}{\mathrm{C}_{1}}$

(2) The equilibrium solution of railway bureau's expected income

The equilibrium solution of railway bureau's expected income $\mathrm{Y}_{2}$ is:

$$
\mathrm{Y}_{2}=\mathrm{P}_{4} * \sum_{\mathrm{i}=1}^{8}\left(\mathrm{q}_{\mathrm{i}} * \mathrm{~S}_{\mathrm{i} 2}\right)+\left(1-\mathrm{P}_{4}\right) * \sum_{\mathrm{i}=9}^{16}\left(\mathrm{q}_{\mathrm{i}} * \mathrm{~S}_{\mathrm{i} 2}\right)
$$


$\mathrm{P}_{4}=\mathrm{m}+\frac{\mathrm{P}_{1}+2 * \mathrm{P}_{2}+3 * \mathrm{P}_{3}}{6}(\mathrm{M}-\mathrm{m})$, where $0<\mathrm{m}<\mathrm{M}<1$

In order to find the maximum value of the above function, the first derivative of the probability of railway bureau's refinement $\mathrm{P}_{2}$ is calculated and made to be equal to zero.

The solution result is: $P_{1}\left(C_{1}+a C_{2}\right)+\frac{M-m}{3}\left[\left(R_{2}-\right.\right.$ $\left.\left.\mathrm{R}_{3}\right)+\left(\mathrm{L}_{2}-\mathrm{L}_{3}\right)\right]+\left(1-\mathrm{P}_{3}\right) * \mathrm{bC}_{3}-\left(\mathrm{C}_{1}+\mathrm{C}_{2}\right)=0$

(3) The equilibrium solution of China State Railway Group's expected income

The equilibrium solution of China State Railway Group's expected income $Y_{1}$ is:

$$
\begin{aligned}
& \mathrm{Y}_{1}=\mathrm{P}_{4} * \sum_{\mathrm{i}=1}^{8}\left(\mathrm{q}_{\mathrm{i}} * \mathrm{~S}_{\mathrm{i} 1}\right)+\left(1-\mathrm{P}_{4}\right)^{*} \sum_{\mathrm{i}=9}^{16}\left(\mathrm{q}_{\mathrm{i}} * \mathrm{~S}_{\mathrm{i} 1}\right) \\
& \mathrm{P}_{4}=\mathrm{m}+\frac{\mathrm{P}_{1}+2 * \mathrm{P}_{2}+3 * \mathrm{P}_{3}}{6}(\mathrm{M}-\mathrm{m}), \text { where } 0<\mathrm{m}<\mathrm{M}<1
\end{aligned}
$$

In order to find the maximum value of the above function, the first derivative of the probability of China Railway Group strengthens supervision $P_{1}$ is calculated and made to be equal to zero.

The solution result is: $\mathrm{P}_{2}=1+$

$$
\frac{\frac{\mathrm{M}-\mathrm{m}}{6}\left[\left(\mathrm{R}_{1}-\mathrm{R}_{2}\right)+\left(\mathrm{L}_{1}-\mathrm{L}_{2}\right)\right]-\mathrm{C}_{1}}{\mathrm{aC}_{2}}
$$

\subsection{Model Analysis}

(1) $P_{1}=1-\frac{\frac{\mathrm{M}-\mathrm{m}}{2}\left(\mathrm{R}_{3}+\mathrm{L}_{3}\right)+\mathrm{Q}_{3}-\left(1-\mathrm{b} * \mathrm{P}_{2}\right) * C_{3}}{\left(1-P_{2}\right) * \mathrm{C}_{1}}+\frac{\mathrm{C}_{2}}{\mathrm{C}_{1}}$ where $\frac{\mathrm{M}-\mathrm{m}}{2}>0, \mathrm{~b}<1$

When the management cost of railway bureaus and railway stations is high, China Railway Group reasonably suspects that railway bureaus and railway stations may be less willing to refine the railway technical regulations. Therefore, China Railway Group needs to strengthen supervision.

This shows that when railway bureau increases its penalties on railway station, and urges railway station to implement the railway technical regulations, China Railway Group believes that the normative effect could be achieved, therefore it tends relax the supervision; when $\mathrm{R}_{3}, \mathrm{~L}_{3}, Q_{3}$ are large, the enthusiasm of railway station's implementation will inevitably increase to improve efficiency and reduce losses, so China Railway Group believes that there is no need for excessive supervision.
(2) $P_{1}\left(\mathrm{C}_{1}+\mathrm{aC}_{2}\right)+\frac{\mathrm{M}-\mathrm{m}}{3}\left[\left(\mathrm{R}_{2}-\mathrm{R}_{3}\right)+\left(\mathrm{L}_{2}-\mathrm{L}_{3}\right)\right]+(1-$ $\left.P_{3}\right) * b C_{3}-\left(C_{1}+C_{2}\right)=0$

This formula can be reduced to two forms:

(1) $\quad P_{1}=\frac{\left(\mathrm{C}_{1}+\mathrm{C}_{2}\right)-\frac{\mathrm{M}-\mathrm{m}}{3}\left[\left(\mathrm{R}_{2}-\mathrm{R}_{3}\right)+\left(\mathrm{L}_{2}-\mathrm{L}_{3}\right)\right]-\left(1-P_{3}\right) * \mathrm{~b} C_{3}}{\mathrm{C}_{1}+\mathrm{aC}_{2}}$

(2) $\quad P_{3}=1-$

$\frac{\left(\mathrm{C}_{1}+\mathrm{C}_{2}\right)-\frac{\mathrm{M}-\mathrm{m}}{3}\left[\left(\mathrm{R}_{2}-\mathrm{R}_{3}\right)+\left(\mathrm{L}_{2}-\mathrm{L}_{3}\right)-P_{1}\left(\mathrm{C}_{1}+\mathrm{aC}_{2}\right)\right]}{\mathrm{b} C_{3}}$

$=1-\frac{\left(1-P_{1}\right) * \mathrm{C}_{1}+\left(1-P_{1} * \mathrm{a}\right) \mathrm{C}_{2}-\frac{\mathrm{M}-\mathrm{m}}{3}\left[\left(\mathrm{R}_{2}-\mathrm{R}_{3}\right)+\left(\mathrm{L}_{2}-\mathrm{L}_{3}\right)\right]}{\mathrm{b} C_{3}}$

where $\frac{\mathrm{M}-\mathrm{m}}{3}>0, \mathrm{a}<1$

This shows that when China Railway Group's punishment of railway bureau and railway bureau's punishment of railway station increase, they will eventually affect railway station and prompt it to earnestly implement railway technical regulations; when the residual income and final loss of railway bureau are larger, railway station will be more inclined to implement the railway technical regulations carefully to avoid big risks and tend to have higher overall benefits.

(3) $P_{2}=1+\frac{\frac{M-m}{6}\left[\left(R_{1}-R_{2}\right)+\left(L_{1}-L_{2}\right)\right]-C_{1}}{a_{2}}$

where $\frac{M-m}{6}>0, \quad \frac{M-m}{6}\left[\left(R_{1}-R_{2}\right)+\left(L_{1}-L_{2}\right)\right]-C_{1}<$ 0

This shows that the greater the value of residual income and final loss of China Railway Group, the more railway bureau tends to carefully refine the railway technical regulations to avoid big risks and tend to higher overall benefits; when China Railway Group's supervision and punishment are relatively strong, railway bureau tends to be careful and work in accordance with the requirements.

\section{Construction and Simulation Analysis of System Dynamics Model}

\subsection{Construction of System Dynamics Model}

According to the above game analysis of supervision of railway technical regulation, a model based on system dynamics is constructed. Vensim PLE is used to draw flow diagram of the game model of railway technical regulations supervision (Figure 1). 


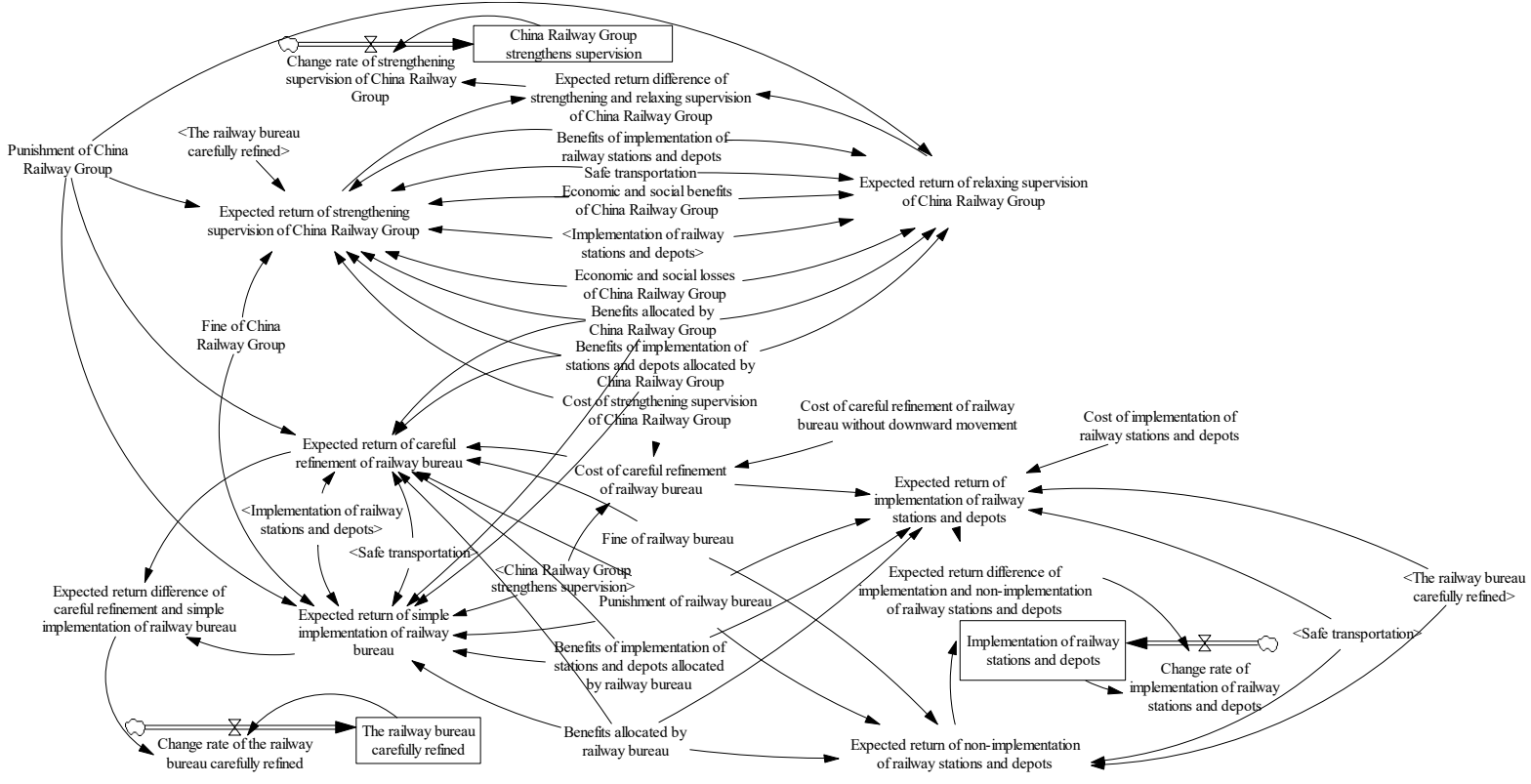

Fig.1 Flow diagram of the game model of railway technical regulation supervision

All the variables involved in this model are from the parameter variables defined in the payment matrix of each game before, and there are 31 variables, including 3 horizontal variables, 3 rate variables ,10 auxiliary variables and 15 constants. The horizontal variables include the supervision of China Railway Group, the refinement of the railway bureau and the implementation of railway stations and depots. The rate variables are the rate of change that affects the behavior of each subject, while the auxiliary variables and constants contain the key factors that affect the expected income of each subject. The functional relationship between the variables is determined by the expected income equation in the previous game model.

\subsection{Simulation Analysis}

The initial value of the model is assumed to be: the unit of simulation period is month, the step size is 1 , and the research period is 100 , that is, INITIAL TIME $=0$, FINAL TIME $=100$, TIME STEP $=1$; and the initial values of each horizontal variables and constants are determined by reference to the relevant literature, as shown in Table 3.

Table 3 Initial values of horizontal variables and constants in the model

\begin{tabular}{|c|c|c|c|}
\hline Variable & $\begin{array}{l}\text { Initial } \\
\text { value }\end{array}$ & Variable & $\begin{array}{l}\text { Initial } \\
\text { value }\end{array}$ \\
\hline $\begin{array}{l}\text { Economic and social benefits of China State } \\
\text { Railway Group }\end{array}$ & 10 & Punishment of State Railway Group & 7.5 \\
\hline $\begin{array}{l}\text { Loss of economic and social benefits of China } \\
\text { State Railway Group }\end{array}$ & 15 & Fine of Railway Bureau & 1 \\
\hline $\begin{array}{l}\text { Benefits allocated by China State Railway } \\
\text { Group }\end{array}$ & 5 & Punishment of Railway Bureau & 3.5 \\
\hline $\begin{array}{l}\text { Benefits of implementation of stations and } \\
\text { depots allocated by China State Railway Group }\end{array}$ & 2.5 & $\begin{array}{l}\text { Benefits of implementation of stations and } \\
\text { depots allocated by Railway Bureau }\end{array}$ & 1 \\
\hline $\begin{array}{l}\text { Cost of strengthening supervision of China } \\
\text { State Railway Group }\end{array}$ & 2 & Benefits allocated by Railway Bureau & 2.5 \\
\hline $\begin{array}{l}\text { No down cost (Railway Bureau carefully } \\
\text { refines cost) }\end{array}$ & 2 & $\begin{array}{l}\text { Implementation cost of railway stations } \\
\text { and depots }\end{array}$ & 2 \\
\hline Fine of China State Railway Group & 1 & Safe transportation & 1 \\
\hline
\end{tabular}

Through the analysis of the game model, the effective strategy of technical regulation supervision mode is as follows: in the technical regulation supervision mode composed of "China Railway Group, railway bureau and railway station ", the three parties can actively participate in the supervision of technical regulations by increasing the rewards and punishments and reducing the cost. In the following, we will carry out simulation around this strategy to analyze the changes of the expected returns of the participants in different regulatory states.

In order to reflect the impact of reward and punishment intensity and cost on the expected return of each participant, it is necessary to exclude the influence of supervision intensity. Therefore, the simulation will 
assume that the supervision intensity of each participant is 0.5. In the adjustment of the three parameters of reward, penalty and cost associated with each participant in the simulation model, it is found that the penalty parameter has the largest impact on the system. Figures 2, Expected return of China Railway Group

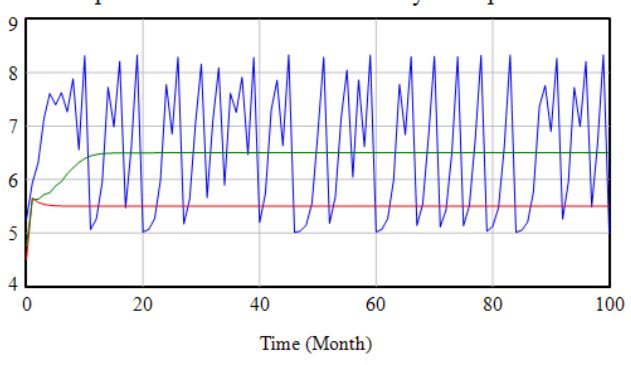

The fines of China Railway Group and Railway Bureau both reduced by 2 time The fines of China Railway Group and Railway Bureau both reduced by half Current

Fig.2 Curve of expected return of China State Railway Group under different penalty multiples
3 , and 4 respectively show the change curve of expected return of China Railway Group, the railway bureau, and the railway stations and depots under different penalty multiples.

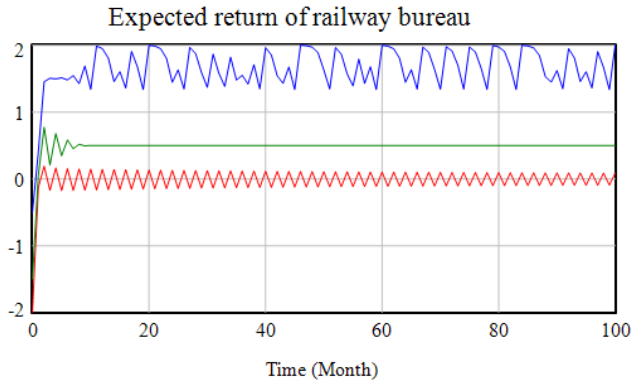

The fines of China Railway Group and Railway Bureau both reduced by 2 tim The fines of China Railway Group and Railway Bureau both reduced by half Current

Fig.3 Curve of expected return of Railway Bureau under different penalty multiples

Expected return of railway stations and depots

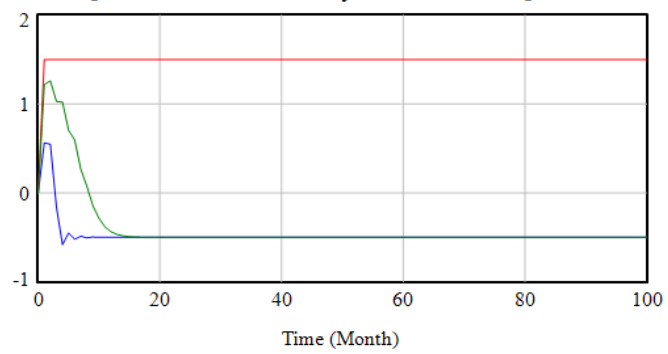

The fines of China Railway Group and Railway Bureau both reduced by 2 tim

The fines of China Railway Group and Railway Bureau both reduced by half Current

Fig.4 Curve of expected return of Railway Stations and Depots under different penalty multiples

It can be seen from the figure that: when the punishment is increased to twice the original, the expected return of the railway bureau will basically remain stable after a rapid rise in a short period of time, and it can also ensure that the stable income is higher than the initial income without any loss. However, when the punishment is increased by 2 times, the revenue of railway stations and depots will drop significantly, which will greatly damage the interests of railway stations and depots. At the same time, the expected return of China Railway Group is unstable, which is not conducive to the stability of supervision system of railway technical regulation. In order to ensure that the return of railway stations and depots are not damaged and to stabilize the Expected return of China Railway Group

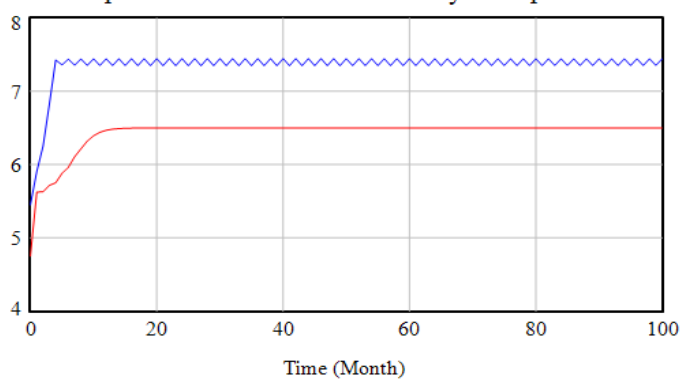

Fines increased by $50 \%$, rewards increased by $25 \%$, costs reduced by $25 \%$ Current

Fig.5 Curve of expected return of China State Railway Group after the adjustment of rewards, punishments and costs income of China Railway Group, it is necessary to increase the reward and reduce the cost at the same time when increasing the punishment. Figures 5, 6 and 7 show that when the punishment intensity increases by $50 \%$ and the reward intensity increases by $25 \%$, that is, the reward and punishment ratio is $1: 2$, and the main cost is reduced by $25 \%$, the expected income of China Railway Group, railway bureau and railway stations and depots will maintain above the initial income after a period of fluctuation. This shows that by increasing the rewards and punishments and reducing the cost, the expected benefits of each participant can be improved, and the stability of supervision can be ensured.

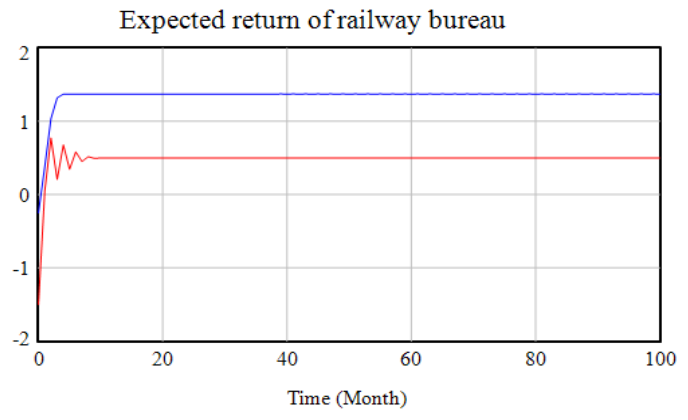

Fines increased by $50 \%$, rewards increased by $25 \%$, costs reduced by $25 \%$ Current

Fig.6 Curve of expected return of Railway Bureau after the adjustment of rewards, punishments and costs 
Expected return of railway stations and depots

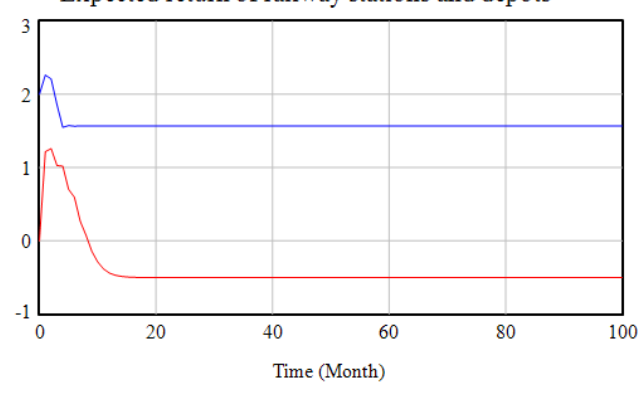

- Fines increased by $50 \%$, rewards increased by $25 \%$, costs reduced by $25 \%$

Fig.7 Curve of expected return of Railway Stations and Depots after the adjustment of rewards, punishments and costs

\section{Summary}

According to the complex game theory and the characteristics of multi-party participation, this paper combines the dynamic game theory with the computer simulation method based on the system dynamics and establishes the game model of the railway technical regulation system, and controls the fluctuation of the game process effectively by solving and simulating the model. Then, it obtains the effective strategies for implementing the supervision mode of the technical regulations: increasing the rewards and punishments to the participants and reducing the costs, which can optimize the supervision mode of the railway technical regulations.

\section{Acknowledgments}

This work was financially supported by Emergency project of National Natural Science Foundation of China "Research on the Technology Roadmap of Frontier New Materials Facing 2035" (No.L1824045).

\section{References}

1. Jin Guo. Discussion on the Hierarchy of Railway Technical Regulations [J]. China Railway, 2019 (01): 40-44.

2. Xin Liu, Yuming Sun, Yonggang Jia, Liang Li, Qiangwei Wen, Fushun Li.[J]. Evolution and Development Trend of Technical Regulations for High-Speed Railways in Our Country, 2019, 41 (06): 5-9 48.

3. Yong gang Jia. Mechanism and Path of Changes in
Railway Technical Regulations [J]. Railway Transport and Economy, 2019, 41 (09): 63-68.

4. Min Kuang, Fuqiang Han. Optimization of Railway Technical Regulation System [J]. Railway Transport and Economy, 2018, 40 (09): 121-126.

5. Yujia Wang, Yonggang Jia, Yuming Sun, Xuefu Liu, Limin Xu. Study on the Construction of Quality Evaluation System for the Preparation of Basic Technical Rules of Railway Administration Group [J]. China Railway, 2019 (08): 80-86.

6. Fuqiang Han, Zhongliang Guan, Xiaojie Wang, Xiang Xie. Railway Regulation Management in China Based on Dynamic Game Theory [J]. Journal of Railways, 2018, 40 (07): 25-32.

7. Xiaotao Zhao.Design and Implementation of Railway Technical Regulation Management System Based on SSM Framework [D]. Beijing Jiaotong University, 2018.

8. Xiaojie Wang.Literature Quantification and Game Research on China's Railway Technical Regulation Management from the Policy Diffusion Perspective. Beijing Jiaotong University, 2018.

9. Kehong Li, Yadong Zhang, Jin Guo, Zicheng Wang.Game Dynamics Analysis of Operation Safety Supervision of High Speed Railway [J]. Journal of Southwest Jiaotong University, 2019,54 (03): 579586.

10. Lu Jia.Evolutionary Game Study on Safety Supervision of Engineering Construction Based on SD [J]. Journal of Nanchang University (Engineering Edition), 2012, 34 (01): 42-48.

11. Shixin Li. Evolutionary Game and Simulation of Car-Hailing Regulation in a Sharing Economy [D]. South China University of Technology, 2019.

12. Min Cheng, Qiancheng Zhu, Damin Dong. Game Study of Construction Safety Supervision Based on System Dynamics [J]. Journal of Safety Science of China, 2011, 21 (12): 73-81.

13. Ya Gao, Hengquan Zhang. Construction Safety Supervision Evolution Game Based on SD [J]. Journal of Engineering Management, 2015, 29 (06): 113-118.

14. Quanlong Liu, Xinchun Li. Control of Effective Stability of the Evolutionary Game of China Coal Mine Safety Supervision [J]. Journal of Beijing University of Technology (Social Sciences), 2015, 17 (04): 49-56. 